\title{
Effect of Leadership Style on Company Performance: Study on Private Company
}

\author{
Rahmat Arfan $^{1}$, Desy puspita ${ }^{2}$, Indra akbar ${ }^{3}$, Arwina sufika $^{4}$, Ricky Ariansyah $^{5}$ \\ \{rahmatarfan@poltekkutaraja.ac.id $\left.{ }^{1}\right\}$ \\ ${ }^{1}$ Manajemen Keuangan Sektor Publik [Politeknik Kutaraja], Indonesia \\ ${ }^{2}$ Manajemen Keuangan Sektor Publik [Politeknik Kutaraja], Indonesia \\ ${ }^{3}$ Administrasi perkantoran [Politeknik Kutaraja], Indonesia \\ ${ }^{4}$ Perjalanan Wisata [Universitas Sumatera Utara], Indonesia \\ ${ }^{5}$ Administrasi perkantoran [Politeknik Kutaraja], Indonesia
}

\begin{abstract}
Purpose of this paper to evaluate how the effect of leadership style with focusing on motivate leader with conflict solution in organization performance with three aspects in organization performance it is creativity, good relations between employer and employee then work ethic on the company. In this paper we use the private company as sample and location is at Aceh with focuses in three big cities which is still in one company it is Banda Aceh, Lhoksumawe and Langsa. From this study, we found a positive correlation between two variables with Moderate relation on regression. From the conclusion, we can explain it is motivated leader and active on conflict solution can influence company performing on aspect creativity then increasing good relation between employee and employer then increasing work ethic.
\end{abstract}

Keywords: Leadership,Company.

\section{Introduction}

A company consists of staff and leaders by implementing vision and mission as a company objective. The Company will be a success by support from good leader and staff. Clearly of vision and mission will not occur without any commitment from a leader in supervising his staff until achieving company goals.

Leadership can be understood as a tool in influencing and moving organizations, a good leader is who can apply their vision to their staff [1]. A leader is a position that can encourage all levels to achieve organizational goals through persuasion and threat, organization use persuasion such as reward and threat such as punishment, these two proses are often applied in many companies. In implementing leadership, a leader needs to motivate staff to stay on the same vision and mission. If a leader cannot control his staff in the same corridor of vision and mission it will cause conflict in the company. Conflict in an organization needs to be resolved by using any suggestion like Standard Operational procedure although it can be an adequate basis for decision making [2]

A leadership is tools which need complicated process, in this process always face long failure but if we still in agreement of company no possible we can get success. Successful will be any meaning of result, one of it is creativity in level staff, the relation between any level in the organization and good ethical work on communication and interaction. Some researcher believes the creativity of staff create by the leader ([3] leader with supervising staff with positive care will increase and build good relation with effective communication [4]. 
Statement of problem on this paper in generally want to find how leadership style ability to achieve a successful company, but in detail we want to find leadership in variable motivation and conflict solution will affect organization performance in variable creativity, the relationship between management and staff, also work ethics and norm of a conducive working atmosphere.

\section{Methodology}

Presented data in this paper is in the quantitative method. Collected data using questioner then the data will transcript to numbers and inputting into the SPSS program after this process analysis will run using statistic methods. The method implemented in this paper is normality, reliability, validity, and regression. The sample is using in this paper taken from PT. Tri Bumi Kutaraja which is this company is one of the private sector company in Aceh with three branches at Banda Aceh, Lhoksumawe and Langsa. All sample used in this paper is 22 people taken from the Sales staff at this company. Collecting data process is doing by questioner with using Likert scale in 17 questions with two main questions is leadership and organization. Negative questions are using in this questioner, which is one question in leadership and two questions in the organization. These negative questions are using to evaluate respondent are answering all question seriously. Data analysis in this paper using statistic by SPSS program, several analyze running by a program that is normality, reliability, validity, and regression. In normality, the method using in this segment is Skweenes method which is the result will be normal if result between -2 and 2 in the skewness test [5], in reliability test was conducted to estimate the level of reliability of the data obtaining from questioner by calculating Cronbach alpha. The questioner can we state reliable base on Cronbach alpha bigger than 0.60 , and if Cronbach alpha value less than 0.60 then the item is not reliable [6].

\section{Result and Discussion}

Base On demographic data on this table below the gender composition of the respondent is slightly dominated by male respondent 30 people in $86 \%$ and 5 people female in $14 \%$.

\begin{tabular}{llll}
\hline No & Gender & Total & $\%$ \\
\hline 1 & Male & 30 & $86 \%$ \\
\hline 2 & Female & 5 & $14 \%$ \\
\hline
\end{tabular}

For a position in the company there is have ten positions, start at highest is level three, level two, and level one. Commercial Manager is the highest level in the company and continues to Human Resource Manager, Finance Manager, Territorial Manager, Management Information system, Sales Executive, Marketing executive, admin finance, and Office Boy.

\begin{tabular}{lll}
\hline No & Position & Total \\
\hline 1 & Commercial Manager & 1 \\
\hline 2 & Human Resource Manager & 1 \\
\hline 3 & Finance manager & 1 \\
\hline 4 & Territorial Manager & 4 \\
\hline 5 & Management Information System & 1 \\
\hline 6 & Sales Executive & 18 \\
\hline 7 & Marketing Executive & 4 \\
\hline
\end{tabular}




\begin{tabular}{lll}
\hline 8 & Admin Finance & 2 \\
\hline 9 & Admin Depo \& Logistic & 2 \\
\hline 10 & Office Boy & 1 \\
\hline
\end{tabular}

\subsection{Reliability Test}

From data after analyzing by SPSS, we get the result of reliability as listed below.

\begin{tabular}{llll}
\hline Variable & Total Items & Cronbach alpha & Explanation \\
\hline Leadership Style $(\mathrm{X})$ & 8 & 0.824 & Reliable \\
\hline Organizasion Performance (Y) & 9 & 0.673 & Reliable \\
\hline
\end{tabular}

On the table, we can see all variable on the questioner in reliable base on Sarjono and Julianita (2001) state about the reliability of variable is must bigger than 0.60 if the data is less than 0.60 variables is not reliable. From the result we can make a decision there is leadership style and organization performance is reliable variable base on reliability analysis.

\subsection{Validity Test}

Validity test was conducted in this paper to measure the questioner can use appropriately. All instrument tested by Pearson Correlation to find validity and correlation between variable. This test is doing to find validity by comparing Cronbach alpha 0.05 and sig. value result from the correlation table [7].

\section{Correlations}

\begin{tabular}{lllll}
\hline \multicolumn{5}{c}{ Correlations } \\
\hline \multirow{3}{*}{ Motivation } & \multicolumn{5}{c}{ Creativity } & Relationship & Ethic \\
\cline { 2 - 5 } & Pearson Correlation &, $446^{*}$ &, $475^{*}$ &, $541^{* *}$ \\
\cline { 2 - 5 } & Sig. (2-tailed) &, 037 &, 025 &, 009 \\
\cline { 2 - 5 } Conflict & $\mathrm{N}$ & 22 & 22 & 22 \\
\cline { 2 - 5 } & Pearson Correlation &, 373 &, 336 &, $458^{*}$ \\
\cline { 2 - 5 } & Sig. (2-tailed) &, 087 &, 126 &, 032 \\
\cline { 2 - 5 } & $\mathrm{N}$ & 22 & 22 & 22 \\
\hline
\end{tabular}

result of validity from Pearson Correlation analysis has to show there has been a significant correlation and validity between motivation, creativity staff, relationship, and ethical work but in conflict validity and correlation occur between conflict management and ethical work, then not occur between conflict management in creativity and relationship.

\subsection{Regression test}

Regression was used to explore the best prediction among variable. This analysis used when the researcher wants to predict a continuous dependent variable from a number of independent variables [8]. On this step regression will do in two ways there is analysis between conflict management with organizational performance and motivation with organization performance.

\subsubsection{Regression between conflict management and organization performance}

Between variable conflict management and organizational performance, the result is:

\section{Coefficients}

\begin{tabular}{lcccc}
\hline Model & $\begin{array}{c}\text { Unstandardized } \\
\text { Coefficients }\end{array}$ & $\begin{array}{c}\text { Standardized } \\
\text { Coefficients }\end{array}$ & t & Sig. \\
\hline
\end{tabular}




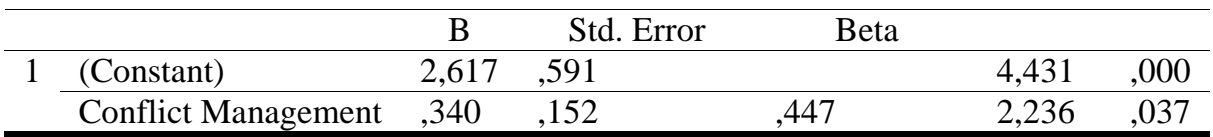

a. Dependent Variable: Organization Performance

Base on the table, the result show were there have correlation on conflict management and organization performance base on Sig. t 0.037 less than Cronbach Alpha 0.05 and the equation from the result is:

$$
\mathrm{Y}(\text { organization performance })=2,617+0.340 \mathrm{X}
$$

Refer to that equation there is have a positive relationship between organizational performance and conflict management, then if one-point increase in conflict management, organization performance will increase in 0.34 unit.

\subsubsection{Regression between Motivation and organization performance}

Between variable Motivation and organizational performance, the result is:

\section{Coefficients}

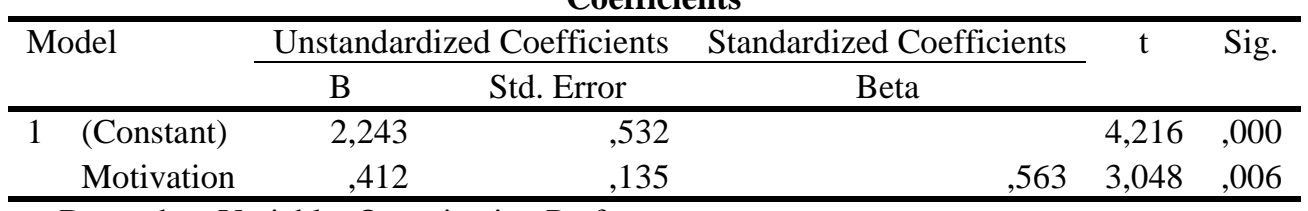

a. Dependent Variable: Organization Performance

Between this variable, the result in t-test indicates the value have to the correlation between an independent and dependent variable with the result is 0.006 and it show value is less than Cronbach alpha 00.05 , and the conclusion in partial between this variable have correlation and the equation is:

$$
\mathrm{Y}(\text { organization performance })=2.243+0.412 \mathrm{X}
$$

Refer to the equation there have a positive impact between organization performance and motivation, with one unit increase in motivate will relate increase 0.412 in organization performance.

\subsection{Simultant Test (F)}

This test was conducted to correlate between all variable dependent and independent [9]. Base on the test was doing the result is:

\begin{tabular}{lllllll}
\hline \multicolumn{7}{c}{ ANOVA } \\
\hline Model & Sum of Squares & Df & Mean Square & F & Sig. \\
\hline 1 & Regression &, 833 & 2 &, 417 & 4,540 &, $024^{\mathrm{b}}$ \\
& Residual & 1,744 & 19 &, 092 & & \\
\multicolumn{2}{l}{ Total } & 2,577 & 21 & & & \\
\hline
\end{tabular}

From the table, the result explains there has simultan correlation between all variable independent and dependent variable at value 0.024 less than Cronbach alpha in 0.05. 


\section{Conclusion}

Result of this paper found base on partial test and simultant test, leadership style in motivation and conflict management has significant influence to organizational performance in variable creativity of worker, the relation between leader and staff and ethical work. Leadership style in conflict management not always influence creativity staff and relation between staff and leader, it is because they can separate between work and personal relationship. A company needs to maintain the way they motivate staff and the way they manage conflict inside the organization, to keep in high organization performance and to prove their worth to get the best company in 2018, and hope can get the same result in 2019.

\section{References}

[1] E. Syarifudin, “TEORI KEPEMIMPINAN,” ALQALAM, 2019.

[2] R. Tanter, "International System And Foreign Policy Approaches: Implications for Conflict Modelling and Management," World Polit., vol. 24, no. S1, pp. 7-39, 1972.

[3] K. S. Jaussi and S. D. Dionne, "Leading for creativity: The role of unconventional leader behavior," Leadersh. Q., 2003.

[4] M. Jensen, "Journal of Social and Personal,” J. Soc. Pers. Relatsh., 1986.

[5] D. P. Doane and L. E. Seward, "Measuring skewness: A forgotten statistic?," J. Stat. Educ., 2011.

[6] H. Sarjono and W. Julianita, "Pengenalan SEM (Part 2)," sbm.binus.ac.id, 2015. .

[7] Nunnaly 1978, "Coefficient alpha: Interpret with caution," Eur. J. Psychol., 2013.

[8] B. G. Tabachnick and L. S. Fidell, Using multivariate statistics. 2012.

[9] Ghozali, "g.pdf," in AplikasiAnalisis Multivarian dengan program IBM SPSS, 2010. 